\title{
Literárnoestetické názory Ĺudovíta Štúra a Detvan Andreja Sládkoviča
} Marta Fülöpová

\author{
FÜLÖPOVÁ, M.: L'udovít Štúr's literary aesthetic views and Andrej \\ Sládkovič's Detvan \\ SLOVENSKÁ LITERATÚRA 68, 2021, No. 2, p. 97-108 \\ DOI: https://doi.org/10.31577/slovlit.2021.68.2.2 \\ ORCID ID: https://orcid.org/0000-0002-3732-8144
}

Key words: Andrej Sládkovič, Detvan, Ĺudovít Štúr, dramatic poetry

The article investigates the relationship between literary aesthetic opinions of L'udovit Štúr (1815-1856) presented in his lectures in the early 1840 os and the poetics of Andrej Sládkovič's (1820 - 1872) Detvan (1846, published in book form in 1853). The article offers an interpretation of the poem through the prism of the topics, motives and poetic devices that might suggest that Sládkovič was acquainted with Štúr's theoretical work and consciously attempted at a realisation of Štúr's idea of Slavic poetry. The reading presented in the article pinpoints the latent dramatic potential of Sládkovič's poem that is coded in its performative elements. Discussing the poem as belonging to the genre of dramatic poetry is justified by such typological characteristics as syncretism of its lyric and epic parts and an increased level of performativity. Detvan as a dramatic poem is discussed in the wider context of Sládkovič's literary aesthetic views and those of his activities that are linked with dramatic art.

Klúčové slová: Andrej Sládkovič, Detvan, L'udovit Štúr, dramatická poézia

ásnickú skladbu Detvan, ktorú Andrej Sládkovič dokončil v roku 1846, ale vydal až v roku 1853, hodnotili už jeho súčasníci vel'mi kladne. L'udovít Štúr o nej v roku 1852 v liste Jozefovi Miloslavovi Hurbanovi napísal, že sa z nej dajú vybrat' „pekné kúsky“ (Ambruš 1956: 258), pre Jána Kalinčiaka to bola „klasická báseň“ (Kalinčiak 2009: 436), pre Mikuláša Dohnányho-z vyjadrenia v liste A. Sládkovičovi z 26. marca 1852 - ,sladký pokrm“ (Kraus 1980: 97). 
98 Literárny historik Jaroslav Vlček ju o niečo neskôr označil za vel'kú báseň, v ktorej jej tvorca „umelecky stelesnil celé obrovské Mladé Slovensko“ (Vlček 1954: 327).

Podoba slovenskej poézie bola v polovici 19. storočia, v dobe vzniku Detvana, definovaná vel'mi jasne. Základ uvažovania o ideálnom slovanskom (aj slovenskom) literárnom diele tvorili prednášky L'. Štúra, ktoré poznala väčšina dobových autorov, medzi nimi aj A. Sládkovič. L'. Štúr nepredostrel len deskriptívnu teóriu literatúry, ale aj estetický kánon, normatív, podla ktorého mali básnici postupovat pri tvorbe slovenskej poézie. Štúrovi nasledovníci si uvedomovali, že idey, ktoré s nadšením prijímali, sú zaväzujúce, určovali totiž, akú úroveň by mali dosiahnut literárne diela, ktoré mali ako slovenskí básnici napísat'.

V štúdii sa venujem jednej z možných realizácií Štúrových estetických názorov, analýze vztahu medzi básnickým stvárnením Detvana a Štúrovými názormi na slovenskú literatúru, a hl'adám odpoved'na otázku, či je možné považovat Sládkovičovho Detvana za umeleckú realizáciu Štúrových ideí.

A. Sládkovič sa stretol so Štúrovými myšlienkami ako študent evanjelického lýcea, ked'Štúr začal po svojom návrate z Halle začiatkom roka 1841 znova vyučovat' (Kraus 1972: 35), hoci zachované odpisy Štúrových prednášok pochádzajú až z roku 1844, teda z doby, ked'Sládkovič už nebol v Prešporku (Vongrej 1987: 7). Štúrove prednášky sa vyvíjali organicky, dá sa preto predpokladat', že ich hlavné myšlienky sa medzi rokmi 1841 - 1842 a rokom 1844, ked'ich Štúrovi študenti zapísali, zásadne nemenili. Sládkovič sa zdržiaval v Prešporku v rokoch 1840 - 1842. Kalinčiakova poznámka, podl'a ktorej Štúrove prednášky najusilovnejšie zaznamenával Štefan Launer (1821 - 1851), spolužiak a jeden z najbližších kamarátov A. Sládkoviča (Kalinčiak 2009: 428), nepriamo naznačuje, že aj to mohol byt'kanál, cez ktorý sa Štúrove idey dostávali k Sládkovičovi. Podl'a Cyrila Krausa Sládkovič v Halle „priam podl'ahol Heglovmu vplyvu“, čomu mohla predchádzat' predpríprava v podobe Štúrových ideí, silno inšpirovaných Heglom (Kraus 1972: 39). Ako uvádza C. Kraus, v zachovaných dokumentoch sa nenachádzajú bližšie informácie o tom, ako pôsobili Štúrove prednášky na Sládkoviča (Kraus 1972: 39). Zachovala sa iba Kalinčiakova poznámka v jeho Rozpomienkach na Ondreja Sládkoviča: „Ondrejko náš vlastne len od Štúra v Požuni dostal smer budúceho žitia slovenského“ (Kalinčiak 2009: 428). J. Vlček uvádza, že Sládkovič bol jedným z najoblúbenejších Štúrových žiakov (Vlček 1954:324).Z rokov 1842-1846 sa zachovali štyri listy L'. Štúra adresované A. Sládkovičovi (Ambruš 1954:344; Ambruš 1956: 130, 132; Ambruš 1960: 35). Štúr v nich rieši väčšinou finančné otázky, platby za posielané knihy a informuje Sládkoviča o aktuálnych udalostiach (vydávanie novín a jazyková otázka). V spore o spisovný jazyk dával Sládkovičovi rady, akú obranu má napísat proti spisu Hlasové o potřebě jednoty spisovného jazyka pro Čechy, Moravany a Slováky. Sládkovič však nakoniec nenapísal článok, ale báseň Ohlasy, ktorú L'. Štúr uverejnil v Orle tatranskom (Sládkovič 1846). Podl'a Jozefa Ambruša, editora Štúrovej korešpondencie, sú v tejto básni „rozhodne stopy“ inštrukcií L'. Štúra (Ambruš 1956: 401).

Vztah medzi Štúrovými názormi a umeleckou koncepciou Sládkovičovho Detvana si všimli viacerí interpreti. Podla J. Kalinčiaka Sládkovič „previedol“ do svojej tvorby Štúrovo učenie: 
„Ked'Ludovít Štúr v pojednaní svojom povedal, že sa u nás príroda s duchom l'udským v básnictve objíma, mal úplnú pravdu, a Sládkovič to v básňach svojich aj úplne previedol. Príroda žije v človeku a človek v prírode. V Maríne vidíš citmi slovenskými kraje vychované; v Detvanovi je Martinko náš ako zbojnícka Pol'ana hora, a toto je nášho pevca lúba rodinná postava“" (Kalinčiak 2009: 436).

Kalinčiak nenavodzuje medzi Detvanom a Štúrovými myšlienkami kauzálny vztah, skôr organický, vyplývajúci z toho, že Štúr „mal pravdu“ a Sládkovič túto pravdu realizoval. Obraznost' Maríny a Detvana spája s „ozvenou Štúrových myšlienok“ aj Pavol Vongrej, ked'uvažuje o tom, že Sládkovič pravdepodobne mohol poznat'Štúrove myšlienky (Vongrej 1987:16-17). ${ }^{1}$ Podobne aj C. Kraus usúvztažňuje stvárnenie protagonistu Detvana so Štúrovými estetickými postulátmi o epickej poézii, prezentujúc dielo ako ich praktickú modifikáciu (Kraus 1972: 202).

\section{Spoločné prvky Detvana a Štúrových prednášok}

Skutočnost', že A. Sládkovič poznal literárnoestetické názory L'. Štúra formulované v jeho prednáškach, potvrdzujú nateraz iba nepriame dôkazy, ${ }^{2}$ no detailná analýza Detvana a porovnanie básne s literárnoestetickými názormi L'. Štúra ukazujú na viaceré styčné body.

Harmónia. Umelecké diela napísané v duchu Štúrových ideí majú byt' harmonické, majú smerovat' k pokoju (Štúr 1987:46-48). Tento prvok možno identifikovat' v idylickosti a biedermeierovskej harmonickosti Detvana, ktorá mohla popri iných zdrojoch pramenit' aj v predstave slovanskej poézie.

Prírodné témy. Medzi „predmety“ lyrickej poézie patria podla Štúra vlast', národ a láska (ústredné témy Detvana), ale aj „vyjadrenie“ prírody. V rámci prírody vyčleňuje Štúr skupinu objektov, ktoré sú u Slovanov zvlášt' oblúbené a najlepšie zobrazujú ich povahu a dušu, a preto majú mat' miesto aj v poézii. Sú to lipa, hory, rieky, včely, lastovička, sokol, holub, hviezdy, zora, mesiac a slnko (Štúr 1987: 66-67). V Detvanovi sa objavujú všetky tieto motívy okrem lastovičky, sokol však patrí medzi ústredné symboly skladby.

Zväzok prírody a ducha v symbole sokola. Slovanskú poéziu má podl'a Štúra charakterizovat' ,zväzok medzi prírodou a duchom“ (Štúr 1987:50). Ako príklad uvádza spojenie medzi mládencom a jeleňom z Rukopisu královédvorského, vystupujúcich ako ,jedno“ (Northrop Frye nazýva tento jav analogickou obraznostou; Frye 2003: 178). Podobná symbolizácia prírody tvorí aj kostru Detvana - Martinov osud je spojený s osudom sokola. Martin má „sokolie oči“, je nazývaný „sokol-šuhaj“, ktorý „lieta si st'a sokol mladý“. Ked'z náhleho popudu zabije

1 P. Vongrej predpokladá, že L'. Štúr svoje prednášky v podobnej forme prezentoval už aj skôr (Vongrej 1987: 7).

2 Nepriamym dôkazom môže byt' napríklad citát z listu A. Sládkoviča (podpísaný Ondřej Braxatoris) sestre Karolíne, napísaný v Prešporku 30. marca 1841: „Úpřimne milovaná Sestro! Tá rozkošná věrného brata k úpřimné sestre láska; ten sladký cit, které srdce k srdci váže, duši s duší spojuje těch, jenž jednoho otce, jedné matky dítkami jsou; to srdečné, úpřimné myšlení těch, jenž v drahém, milém otcovském domě spolu nevinné dětinské hričky přežili; ušlechtilé city i mne ke psání tomuto posadili“ (cit. podl'a Kraus 1970: 22). Táto pasáž zodpovedá názorom L'. Štúra, ktorý považoval rodinnú lásku za jadro slovanskej poézie a v jej rámci zdôrazňoval tri citové väzby, objavujúce sa v literatúre: lásku rodičov k najmladšiemu synovi, lásku najmladšieho syna k rodičom a lásku sestry a brata (Štúr 1987: 68-69). 
100 sa sám stane král'ovým „sokolom“-vojakom, ktorýbude „pol'ovat" na král'ových nepriatel'ov a bude plnit' jeho rozkazy. $V$ obraznosti slovenského romantizmu je sokol súčasne ústredným symbolom národa (presnejšie mladých reprezentantov národného hnutia). Sám Štúr ho vo svojich prednáškach uvádza ako oblúbeného posvätného vtáka Slovanov, ktorý je často ospevovaný ako „vták bystrý, prenikavých očú “(Štúr 1987: 67).

Rodina. Najdôležitejším objektom slovanskej lyriky má byt' podla Štúra rodina (Štúr 1987: 66) a láska v nej. Rodinná láska je u Štúra nadradená romantickej, pretože tá je podl'a neho sebecká, hl'adá iba vlastné uspokojenie, ale láska v rodine hladí na štastie ostatných (Štúr 1987: 69). V Detvanovi sú tiež zobrazené rodinné vztahy. Pri tejto téme sa však Sládkovič vzoprel štúrovskému modelu: dominantnou témou skladby je vztahah romantickej lásky medzi Martinom a Elenou (ktorý však Irena Bilińska charakterizuje ako lásku pokojnú, priam manželskú; Bilińska 2014: 738). Objavujú sa aj scény s Martinovým otcom a matkou, Martin spomína bratov, Elena matku. Väčšina týchto scén je marginálna, vymyká sa centrálnej dejovej i reflexívnej línii. ${ }^{3}$ Zmienky o otcovi a matke sú sporadické a ich vynechanie by nijako nenarušilo kompozíciu diela. Vysvetlením tohto javu môže byt', že Sládkovič vytvoril tieto epizódy preto, aby nimi zachytil katalóg rodinných citových väzieb, ktoré majú byt' podl'a L'. Štúra povinnou výbavou slovanskej poézie.

Slovanská hrdinskost'. Motív lúčenia. Boj proti pohanom. Za vzor slovanskej hrdinskosti považuje Štúr boj krestanských slovanských bohatierov proti pohanom (Štúr 1987: 72). Tvrdí, že slovanská spoločnost' sa má dopracovat' $\mathrm{k}$ politickosti vytrhnutím sa $\mathrm{z}$ rodinného života a konaním (bojom) $\mathrm{v}$ prospech pospolitosti (Štúr 1987: 70). Poetickou realizáciou tohto postupu sú podla jeho názoru piesne, ktoré opisujú lúčenie šuhaja od rodiny, bolest' nad stratou „domovej lásky“ a odovzdanie sa vyššiemu životu a poslaniu. Detvan realizuje tieto idey: zobrazuje Martinovu bolest' z opustenia domova a blízkych, v skladbe je viacero scén lúčenia. Martin odchádza od rodiny, aby slúžil královi (tento moment možno vysvetlit ako oddanie sa službe pospolitosti) a bojoval proti pohanom, ${ }^{4}$ čím napíňa Štúrov program národnej poézie.

Hrdina. Napriek neodškriepitel'nej idealizácii slovanskej poézie sa Štúrovo ponímanie konkrétnej práce pre národné spoločenstvo vyznačovalo pragmatizmom a legalizmom. Pragmatický je v tomto zmysle aj Detvan: pod jeho tematiku sa podpisuje potreba umiestnit' slovenského hrdinu v (uhorských) dejinách. Prítažlivý hrdina slúži na posilnenie národného povedomia v intenciách romantického

3 „Milá mu mati, otec mu milý, / drahý mu brat, sestra drahá, / rád má domčok, kde dedovia žili, / žertvy času, žitia vraha: / ale bárs aj noc háje pokryla, / hudba tak sa mu do srdca vryla, / že nevie s ňou šuhaj zdolat"“" (Sládkovič 1961: 202).

4 Štúr vo svojich prednáškach uvádza báseň Janka Krála Zverbovaný ako príklad lúčenia, ked',,šuhaj [...] vyššiemu životu sa poddáva a rodinu preto zanecháva“ (Štúr 1987: 74). Pozoruhodné je, že medzi spevom Lapačka a básňou J. Krála existuje spojitost'-Sládkovič sa zrejme inšpiroval básňou J. Krála (Kraus 1972: 191). Vyzerá to, akoby Sládkovič do svojej skladby implementoval scénu, ktorú Štúr opísal ako vzorové dielo slovenskej poézie, čo by opät potvrdzovalo hypotézu o básnikovom zámere napísat' slovanskú poéziu podla Štúrových ideí. Král'ova báseň však vyšla až v roku 1844 (i ked'jej český variant bol napísaný skôr), takže L'. Štúr ju v školskom roku 1841/1842 nemohol použit ako príklad slovenského života, ked' jeho prednášku počúval A. Sládkovič. Navyše, A. Sládkovič bol v kontakte so slovenským národným hnutím, poznal ho, zaujímal sa o súveké dianie, mohol teda poznat aj Štúrov názor na poéziu J. Krála. 
historizmu. Z charakteristík slovanských hrdinov akcentuje Štúr smelost', vytrvalost', poslušnost', nábožnost', pracovitost' a pokoru. Sládkovič sa opiera i o Štúrove idey o povahe národného hrdinu, ktorý mal vychádzat' z národných povestí (Štúr 1987: 84): hlavná postava Detvana, Martin, je štylizovaná podobne ako rozprávkoví hrdinovia folklórnych príbehov - neporazitel'ný, krásny, nebojácny, nábožný, poslušný královi. Podobne interpretuje hrdinu Detvana C. Kraus, ako „typ slovenského človeka modelovaného podla predstáv štúrovskej generácie“ (Kraus 1983:128).

Motívy slovanského pranáboženstva. Farby. Tátoš. Gradácia. L. Štúr sa vo svojich prednáškach obšírne venuje aj slovanskému pranáboženstvu. V Detvanovi sa na Eleninej parte objavujú biela, zelená a červená farba (strofa 189), čo sú farby, ktoré L'. Štúr považuje za farby božstiev v starom slovanskom náboženstve. ${ }^{5}$ V rozprávkovom kontexte spomenutom pri štylizácii hrdinu možno Martinovho koňa získaného od král'a ${ }^{6}$ interpretovat ako tátoša. Štúr ho pokladal za pôvodný slovanský mytologický prvok (tátoš v službe dobrých bohov verne sprevádza svojho pána a „lietajúc k cielu pomáha“; Štúr 1987: 78). Upozorňuje aj na posvätnost' čísla tri v povestiach (napríklad hrdinovia podstupujú tri skúšky a trikrát bojujú; Štúr 1987: 85). Podobné trojstupňové opakovanie motívu používa v Detvanovi aj Sládkovič: hlavný hrdina Martin bojuje tri razy (so sokolom, so zbojníkmi, s král'ovskými sluhami), tri razy sa stretáva s král'om Matiášom, pričom ich vztah sa naprieč stretnutiami vyvíja a Martin v ňom postupne nadobúda prevahu. I ked' Štúr sa najobšírnejšie venuje motívom zakliatia a odkliatia, v Detvanovi nemá tento motív, s ohl'adom na mimetický charakter skladby, dôležitú úlohu.

Vztáah lyrického a epického. Epika mala podl'a L'. Štúra zobrazovat',„dej“ bez reflexie; „,básnik “v nej nemal byt' prítomný (Štúr 1987:53), a mala zobrazovat' boj a odpor s „platnostou za ludstvo“(Štúr 1987:56). Detvan tieto kritériá nespíňa, lyrické pasáže tvoria dôležitú čast' diela a jeho dej nemá univerzálny, dokonca ani národný dosah. Prítomnost' epického deja však nemožno popriet: Detvan je synkretický lyricko-epický útvar. V lyrických častiach sa Detvan v mnohom zhoduje so Štúrovými ideami.

Dvojdomost' Detvana riešili takmer všetci jeho interpreti. Žánrovo skladbu umiestňovali na škále od eposu (Vajanský 1956:321) po idylu (napríklad Winczer 1983: 336), charakterizovali ju ako byronovskú poviedku (Kleinschnitzová 1958: 365), epicko-reflexívnu báseň (Šmatlák 1958: 295), lyricko-epický útvar (Kraus 1972: 167), heroicko-idylický epos (Klátik 1977:214) či biedermeierovský idylický epos (Bilińska 2014:737) -žánrová paradigma je naozaj rozsiahla. ${ }^{7}$ Detvana však možno žánrovo definovat' aj aplikáciou iného označenia, prostredníctvom pojmu dramatická poézia. Táto kategória prepájajúca lyriku a epiku bola prítomná v širšom súdobom literárnoteoretickom myslení a objavovala sa aj v Štúrových prednáškach. V nasledujúcej časti chcem preto poukázat' práve na možnost' tohto žánrového označenia. ${ }^{8}$

5 Popri zelenej farbe uvádza L'. Štúr plavú farbu (Štúr 1987: 76).

6 V rukopise Detvana mal spev Slatinský jarmok motto, dvojveršie „Koníčok môj vraný / od král'a mi daný“ (Kraus 1972: 184).

7 Uvažovat možno aj o funkčnosti žánru romance, ako ju chápe N. Frye (2003: 49-50).

8 I. Bilińska poukazuje tiež na využívanie epických a lyrických prvkov obohatených o dramaticko-divadelnú stránku, čo odvodzuje od poetiky biedermeieru (Bilińska 2014: 736). 
Štúr považoval dramatickú poéziu za najcennejšiu formu umenia vôbec. Na základe jeho poznámok sa však nedá jednoznačne zistit', čo presne chápal pod týmto termínom. ${ }^{9}$ Zápisy prednášok, v ktorých sa venoval danej otázke, sa stratili (Čúzy 2004: 66), o téme sa zachovalo iba pár jeho roztrúsených poznámok. K dramatickej poézii sa vyjadruje napríklad pri základnej charakteristike epiky. Konkrétne príklady dramatickej poézie uvádza Štúr pri charakteristike piesní ukrajinského (v jeho terminológii maloruského) kmeňa, ktorý pokladá za jej reprezentanta. ${ }^{10}$ Nie je však jednoduché dešifrovat', čo pod pojmom „dramatickost'“ chápal. Pravdepodobne mu išlo o zobrazenie vnútorného boja postavy, procesu jej rozhodovania vedúceho k následnému konaniu. V jeho vnímaní bol vnútorný dramatický konflikt u postáv v ukrajinských piesňach daný napätím medzi dvoma princípmi: verejným a domácim životom, hrdinstvom a rodinou. Toto napätie považuje L'. Štúr za osnovu dramatickej poézie (Štúr 1987: 96). Ilustruje to piesňami o rozlúčke kozáckeho syna s matkou pred odchodom do vojny. Tieto texty uvádza ako stopy skutočnej dramatickej poézie, ktorá mala byt' rozvinutá až v budúcnosti. $\mathrm{V}$ tomto zmysle L'. Štúr nepoužíva termín dramatická poézia len na označenie veršovaných útvarov určených na inscenáciu. Naopak, texty, ktoré uvádza ako príklady dramatickej poézie, zväčša dialogické spevy, neboli určené pre javisko, no boli performatívne. Štúr takto zarad'uje k dramatickej poézii osobité útvary, o ktoré sa neskôr mali tematicky opierat' slovanské drámy. Táto Štúrova pragmatická koncepcia sa líši od Heglovej estetiky, kde sa pod termínom dramatická poézia rozumie (veršovaná) dráma určená na scénické prevedenie (Hegel 1970:352).

Náplň jednotlivých literárnoteoretických termínov sa v čase mení, ani literárne druhy nie sú výnimkou (Veltruský 1999: 8-9). Dramatické dielo v 19. storočíi1 nemuselo znamenat' nutne text určený na inscenovanie. ${ }^{12}$ Existovali aj kabinetné hry, knižné drámy, ktoré formálne spĺn̆ali podmienky kladené na drámu v bežnom význame slova, ale neboli primárne určené na javiskové stvárnenie. ${ }^{13}$ N. Frye uvádza, že dramatická forma básne neznamenala v romantizme výlučne javiskové prevedenie, niektorí romantici dokonca považovali javiskové drámy za „nečisté formy“, ktoré narušujú pôsobenie individuálneho výrazu (Frye 2003: 284). Romantickí autori narušovali čistotu žánrov a ich hranice programovo. Jednak ako gesto vzdoru voči predchádzajúcej prísne normovanej poetike, ale tiež ako vyjadrenie básnického génia a nového, špecifického vztahu ku skutočnosti,

9 L. Čúzy konštatuje, že ani termín „dramatický“ "nepoužíva Štúr jednoznačne, hovorí o dramatickej osobe aj o epike, ktorá je viac dramatická v súčasnosti (Čúzy 2004: 67).

10 Podl'a L'. Štúra sú predstavitel'mi epickej poézie Srbi a predstavitel'mi lyrickej poézie Slováci (Štúr 1987: 88, 93).

11 Navyše, aj performatívny rozmer „nedramatickej“ literatúry v 19. storočí bol silnejší, než je v súčasnosti. Diela nežili iba knižným životom, literatúra bola aj spoločenskou udalostou; predčítanie a recitácia diel patrili k bežnému programu spoločenských stretnutí i k rodinnému životu vzdelaných vrstiev. Predstavitelia vyššej spoločnosti často zamestnávali spoločníčky či spoločníkov, ktorí mali za úlohu predčítavat' literárne diela rôznej povahy.

12 Podla Hegla „by vlastne žiadna divadelná hra nemala byt' vytlačená, ale tak ako v antike by mal rukopis pripadnút divadelnému repertoáru a dostat' sa čo najmenej do rúk čitatela“" (Hegel 1970: 368).

13 Hegel poukazuje aj na názor obvyklý pre dramatiku jeho doby, podla ktorého usporiadanie drámy na predstavenie bolo považované za nepodstatný prídavok k samotnému dielu. Sám nepovažoval tento „trend“ za nasledovaniahodný (Hegel 1970: 367). 
ktorý spočíval v nepokoji a disharmónii. Hybridné diela boli prítomné aj v slovenskej literatúre, napríklad Sôvety v rodine Dušanovej od A. Sládkoviča, dramatická veršovaná skladba Divadlo duchov nad Tatrami zaradená do Korytnických pohárikov J. M. Hurbana (Hučková 2017: 216-218), skladba J. Krála Strom nesmrtel'nosti alebo Dvanást'slov či L'udská komédia Viliama Paulínyho-Tótha (Mihalková 2015: 176-177). Slovenská romantická dráma bola literátmi považovaná za najvyšší stupeň národnej literatúry, čo však predpokladalo istú úroveň spoločenskej organizovanosti, ktorá nebola pre tvorcov k dispozícii. Preto samotná dramatická tvorba zaostávala za ostatnými literárnymi druhmi. Teoretickým otázkam drámy sa venovali viacerí tvorcovia, prvú ucelenejšiu koncepciu, ktorá sa zachovala, Slovo o dramate slovenskom, napísal Mikuláš Dohnány (1824-1852) počas svojich levočských štúdií v roku 1845 (Mihalková 2015: 177). Jeho úvaha sa sústred'ovala hlavne na vymedzenie tematických oblastí, z ktorých mala slovenská dráma čerpat. Tými bol podla autora samotný slovenský život v rôznych svojich prejavoch (história, prítomnost', povesti). Dohnányho koncepcia drámy je viac nacionálno-etická ako estetická; slovenské literárne diela v súlade s L'. Štúrom považuje za prejav morálnej nadradenosti Slovanov/Slovákov.

Sládkovičova skladba Detvan už na prvý pohlad disponuje mnohými vlastnostami, ktoré sú v zhode so Štúrovou charakteristikou dramatickej poézie aj so súdobým literárnovedným myslením o dráme ${ }^{\mathbf{1 4}}$ (nie však s charakteristikou dramatického diela určeného na javisko). Ako spoločné miesta možno uviest'nasledujúce javy:

Vztah lyriky a epiky podl'a Heglovej teórie drámy. L'. Štúr aj G. W. F. Hegel ${ }^{15}$ považujú dramatickú poéziu za syntézu lyriky a epiky. Hegel sa v Estetike venuje dráme podrobne (Hegel 1970:352-399) a viaceré jeho špecifikácie môžeme nájst' aj v Detvanovi (samozrejme, okrem hlavnej, že to má byt' text určený na inscenovanie): 1. dej podávaný v bezprostrednej prítomnosti ako skutočný, zobrazenie prítomného ludského konania, ${ }^{16}$ čo spíňa aj Detvan; 2. konflikt vyplývajúci z protikladu postáv stojacich proti sebe (Hegel 1970:360) - za také možno považovat' Martina a Matiáša, ktorých rozvíjajúci sa vztah tvorí osnovu deja; 3. za vlastné dramatično pokladá Hegel sebavyjadrenie osobností v boji ich záujmov a v rozpore ich charakterov (Hegel 1970:360) - v Detvanovi sa za podobný boj dá chápat' stret Martina a Matiáša a králova túžba odviest' Martina so sebou; 4. proti sebe nestoja dobro a abstraktné zlo, zdrojom protikladu sú protichodné záujmy štátu a rodiny (Hegel 1970: 385), podobne ako to definuje Štúr pri dramatickej poézii.

Tanečné a hudobné scény. Detvan je napísaný s výrazným vlasteneckým pátosom, čo zodpovedá Štúrovmu programu. Použitím artistnej strofy a zvýšenou štylizovanostou výrazu konštruuje Sládkovič hodnotovo a umelecky vysoko položený mýtus slovenského ludu. Artistnost' umocňujú aj početné

14 Zlatko Klátik pri hl'adaní paralel Detvana v slovanských literatúrach okrem iného upozorňuje na blízkost' tejto skladby s dielom Horský veniec Petra Petroviča Njegoša (1813 - 1851), ktoré sa formuje na rozhraní epiky a drámy a je považované za epos, ale aj za knižnú drámu (Klátik 1977: 189).

15 Podl'a L'. Štúra „, dramatike ale vidíš i jednajúce osoby, ale vidíš i spevca, ktorý tu má príležitost' i svoje city, myšlienky a tak d'alej privádzat"“ (Štúr 1987: 53), podla Hegla je „dramatická poézia tým druhom, ktorý spája v sebe objektivitu eposu so subjektívnym princípom lyriky“ (Hegel 1970: 352). L. Čúzy uvádza, že podl'a L. Štúra „dramatická poézia mala byt' akousi syntézou objektívnej a subjektívnej zložky poézie reprezentovanej epickou a lyrickou poéziou“ (Čúzy 2004: 67).

16 Vo formulácii C. Krausa ide o konkrétne problémy v konkrétnych situáciách (Kraus 1972: 164). 
104 hudobné a tanečné scény, ktoré majú v Detvanovi ústredné miesto, prítomné sú takmer v každom speve ako prvok romantickej poetiky, ktorá preferovala hudobnost' aj v tematickej rovine. ${ }^{17} \mathrm{~V}$ prvom speve slúži tanečná scéna dievčat a Martina na predstavenie hrdinov. Martin neskôr zadumane hrá na svojej fujare, čo Sládkovič doplní reflexiami o povahe národa, ktorá sa manifestuje v jeho hudbe. V druhom speve (Družina) Martina zvábi hudba pastierov, s ktorými si zatancuje pri zvuku gájd. Spev valachov slúži Sládkovičovi na lyrickú tematizáciu nádeje a nastávajúceho sveta slobody. Spev a tanec sú okrajovo spomenuté aj v tret'om speve, kde však dominujú dramatické rozhovory ústredných postáv. Vo štvrtom speve (Vohl'ady) je jediným dejovým momentom stretnutie Eleny s král'om ${ }^{18}$ a Martinom, kde hrá na drumbli. Opis jej zvuku je intímny, lyrický, opät však spojený s reflexiou o umeleckých prejavoch ludu. Piaty spev (Lapačka) sa začína tanečno-hudobnou scénou verbunku. Stanislav Šmatlák upozornil v tomto kontexte na to, že „,subjektívny hlas básnika“ sa ozýva v miestach dejového oddychu (pri Martinovej hre na fujare, pri tanci valachov; Šmatlák 1958: 288), čo možno interpretovat'ako koreláciu s obdobnými javiskovými riešeniami, kde tanečné a hudobné zložky slúžia ako zvukový podklad pre narátora. V texte sa dajú identifikovat' aj d'alšie prvky performatívnosti. Opis výzoru Martina aj Eleny pripomína kostým -S. Šmatlák poznamenal, že pri ich predstavení básnik „počíta s perspektívou“ (Šmatlák 1958: 285). Postavy Martina a Matiáša možno charakterizovat' ako zrkadlové a ich vzt'ah ako prejav zrkadlovej dramaturgie.

Sprítomnenie divákov rozprávačom. Performatívnost' textu zvyšuje aj rozprávač v ich-forme, ktorý vytvára fikčný svet ako vnem: ak je prerozprávaný svet vnímatel'ný, jeho „reálnost'“ sa zvyšuje. Pre tento ciel'často využíva slovesá vnímania. Napríklad v Detvanovi vyzýva na viacerých miestach čitatel'ov, aby sa pozreli na svet, ktorý im predstavuje: „ten l'ud náš pozrime, vrstovníci moji!“ (Sládkovič 1961: 187; zvýr. M. F.). Používanie plurálu evokuje existenciu a prítomnost' divákov, súčasne má aj funkciu vytvorit pocit spolupatričnosti recipientov, participuje na vytvorení predstavy spoločenstva, ktoré daný zážitok spoločne prežíva.

Tri jednoty. Sládkovič dodržiava jednotu miesta približne v intenciách Heglových názorov, ktorý pri tomto vymedzení nie je striktný. Pohyb v priestore zabezpečí podl'a Hegla pre postavy „bohatstvo kolízií, charakterov, epizodických postáv a intermezz“ (Hegel 1970: 356). Dejiskom Detvana je okolie Pol'any, ktoré hlavná postava v priebehu deja neopustí, ale pohybuje sa v ňom. Sládkovič dodržiava aj jednotu času (Detvan sa odohráva v priebehu niekol'kých dní a dej je prezentovaný ako simultánny). Jednotný dej je sústredený okolo vztahu medzi Martinom a Matiášom, k jeho naplneniu smerujú všetky „náhody“ príbehu (napríklad zabitý sokol patrí královi, Martin náhodou stretne zbojníkov, ktorí predtým stretli Elenu).

Pät' spevov - pät' dejstiev. Detvan je členený na pät' rovnako dlhých spevov a kompozíciou pripomína klasické drámy (Freytag 1959). Úvod Vrstovníkom spíňa shakespearovskú1 ${ }^{19}$ schému prológu s prosbou o pozornost' recipientov

17 Podla Aleša Hamana (ako uvádza Fořt 2014: 71).

18 Dialóg Eleny a Matiáša podl'a C. Krausa pripomína dialóg postáv v Sládkovičovom dramatickom torze Nezalúbeni zalúbenci (Kraus 1959: 194).

19 C. Kraus uvádza, že A. Sládkovič už v štyridsiatych rokoch 19. storočia čerpal zo Shakespeara (Kraus 1959: 206). 
(Freytag 1959: 92). Za expozíciu možno považovat' prvý spev (Martin), v ktorom básnik predstaví hlavné postavy a priestor, kde sa dej odohráva. V tomto speve nastane aj moment prvého napätia, udalost', ktorá je „podnetom pre budúci dej“ (Freytag 1959: 95), a táto rozhýbe Martinov osud v inom smere, akým sa uberal dovtedy - Martin zabije sokola. V básnických reflexiách je prítomný aj pohlad na vnútorný nepokoj, na vnútornú drámu postavy, ktorá je však tlmená krestanským nastavením slovenského národného hnutia i poetikou biedermeieru. Druhý spev by mohol reprezentovat' kolíziu, ked' sa dej zauzluje. Martin zabije zbojníka a tento čin pri stretnutí s král'om mu definitívne zmení život. Ústredný, tretí spev (Slatinský jarmok) predstavuje krízu, stredobod diela, kde ,jasne vystupuje do popredia výsledok kolízie“ (Freytag 1959: 101). Dramatickost' scény je zvýraznená scénickým usporiadaním dialógu a teatrálnym rozmerom textu, napríklad formou uvádzania replík postáv:

„Kopa sa k nemu zbehla divákov, / ten stŕpa, tento sa smeje, / tamten nadáva mu do sprostákov, / ten súdi jeho nádeje. / A král' hovorí: Prečos' ho zabil? - / Martin: A či ma sám zlý duch zvábil! - / Král: Neznals' môjho sokola? - / Martin: Hl'a, ked'on, že má stužtičku / a na nej vašu žltú karičku, / pán môj, proti mne nevolä“ (Sládkovič 1961: 231).

Pri tejto scéne je badatel'ná vnútorná performatívnost'scény, prítomnost' obecenstva v rovine samotného deja Detvana. Král' a Martin tu vystupujú pred divákmi, ktorí ich „výkon“ hodnotia. Priznanie Martina je nakoniec vyriešené harmonicky, král'ova pozornost' a dar však znamenajú obrat v deji, vyvolajú u Martina vnútorný konflikt. Štvrtý spev má charakter intermezza (Kraus 1972: 189), lyrického momentu pred záverom, kde Sládkovič d'alej rozvíja vztaha Martina a krála. Martinova dominancia sa zväčšuje: král' musí opustit' scénu a rešpektovat' vítazstvo soka v láske, na Elenu má nárok Martin. Sládkovič sa v tomto speve venuje láske mladej dvojice a anticipuje ich možný rozchod v scéne lúčenia. Záverečný spev možno chápat' ako „katastrofu“ v tom zmysle, že v závere sa Martin vzdáva Detvy a odchádza k vojsku. Je to však idylizujúca, biedermeierovská „,katastrofa“, nie tragická. Spíňa Heglovu predstavu o vyústení do prekonania protikladov, zmierenia napätia (Hegel 1970:386). Král' z lásky k Martinovi prisahá splnit' všetky jeho požiadavky, ked' sa pridá do jeho vojska a opustí Detvu - Martin nadobudne definitívne prevahu nad panovníkom, ktorému diktuje svoje pravidlá. Do vojska odchádza v slovenskom kroji, v „rovnošate“ Slováka vstupuje na javisko dejín.

Prvky Štúrovej koncepcie dramatickej poézie. Dramatická zložka poézie má podl'a Štúra vyplynút z konfliktu medzi „hrdinstvom“ a rodinou. V Detvanovi existuje takto poňaté napätie medzi Martinovým pokojným životom v kruhu prírody a rodiny a jeho túžbou po dobrodružstve i poslušnost'ou královi, ktorý ho povoláva do vojska. Explicitným príkladom štúrovskej dramatickosti sú scény lúčenia Martina s Elenou a rodinou. Ďalším spoločným prvkom so Štúrovým príkladom maloruskej dramatickej poézie sú pohania, pre ktorých hrdinovia odchádzajú do boja (Štúr 1987: 96). V Detvanovi je to vzdialený obraz nepriatel'ov „pohanov-vrahov“, proti ktorým má Martin bojovat' v službách krála. Detvan sa tematicky opiera o ludové povesti, čím sa dotýka aj koncepcie drámy, ako ju prezentoval M. Dohnány. 


定
ti Detvana je jeho operná adaptácia Viliamom Figušom-Bystrým, premiérovo uvedená v Slovenskom národnom divadle v Bratislave v roku 1928, označovaná ako prvý pokus o slovenskú národnú operu (Vajda 1988). Libreto k hudbe napísal básnik Emil Boleslav Lukáč, ktorý zasiahol aj do dejovej línie (okrem iného vypustil Martinov odchod z Detvy). ${ }^{20}$ Za pripomienku stojí tiež fakt, že v roku 1948 bola inscenovaná i Marína (Kročanová 2018: 137-138).

Úvahu o prítomnosti performatívneho rozmeru v Detvanovi podporuje aj Sládkovičov celoživotný záujem o divadelnú tvorbu a jeho d'alšie diela, v ktorých sa opätovne vynára kontakt s dramatikou. ${ }^{21}$ Sôvety v rodine Dušanovej možno charakterizovat' ako filozofickú drámu s ambíciou divadelnej inscenácie, ktorá obsahuje i scénické poznámky. Zachovalo sa tiež viacero dramatických zlomkov A. Sládkoviča, napríklad Mongoli, ktorý podl'a C. Krausa svojimi dejovými zložkami pripomína Detvana. Ako spoločné motívy uvádza C. Kraus scénu lúčenia, historické rámcovanie deja do časov „osmanských vpádov“ aj vlastenecký pátos (Kraus 1972: 175), čo sú prvky, ktoré L'. Štúr považoval za znaky dramatickej poézie. Vo fragmente Mongoli sa okrajovo spomína aj postava Matúša Hudcova, ktorý podl'a C. Krausa „pripomína hrdinu Detvana, Martina Hudcovie“(Kraus 1972:176). Popri písaní dramatických diel sa A. Sládkovič do divadelného života zapájal ako ochotnícky herec a tiež organizátor divadelného života (Kraus 1959: 186). Spolu so Samuelom Jurkovičom založili v Sobotišti Slovenské národné divadlo nitrianske, kde pôsobil ako herec a prekladatel' (preložil Voltairove hry Zaira, Smrt' Cézara a Sokrates) a takisto mal na starosti repertoár (Kraus 1972: 186). Neskôr pôsobil ako teoretik divadelných hier, posudzoval hry posielané na súbeh Matice slovenskej v roku 1866 (Čavojský 1956: 283). Z týchto posudkov sú známe jeho teoretické názory na rôzne otázky drámy, napríklad na jej kompozíciu, postavenie v rámci literatúry a miesto v živote národa. Drámu vnímal A. Sládkovič ako vrchol poézie, pre ktorý je slovenský národ ešte primladý. Za jediné dobré dramatické dielo považoval Chalupkovu hru Kocúrkovo. ${ }^{22} \mathrm{~V}$ súkromnej korešpondencii upozorňoval aj na „mravné nebezpečenstvá a pokušenia“ divadla ${ }^{23} \mathrm{z}$ pohl'adu krestanstva a tradície - bol v prvom rade kňazom, hoci i toto jeho „neliterárne“ povolanie sa vyznačuje istým performatívnym rozmerom. ${ }^{24}$

20 E. B. Lukáč toto svoje veršované operné libreto publikoval aj samostatne pod názvom E. B. Lukáč: Detvan. Libreto opery V. Figuscha Bystrého (Bratislava: Nákladom spisovatel'ovým vydal literárny odbor Umeleckej besedy slovenskej, 1928). Ako sa uvádza v básnikovom personálnom hesle v prvom zväzku Encyklopédie dramatických umeni Slovenska, „celkový plán mu vypracoval V. Figuš-Bystrý, ktorý do hotového textu vložil aj vlastné vsuvky a rôzne lud. piesne“ (Encyklopédia... 1989: 690). Romantická opera V. Figuša-Bystrého však nenaplnila očakávania: „Kompozične a formovo je to však skôr lud. spevohra než dram. útvar, autor v nej cituje a napodobňuje slov. lud. piesne [...] Je to skôr dokument generácie, ktorá sa aj v hudbe usilovala o nár. uvedomenie [...] “ (Encyklopédia... 1989: 365).

21 Život a dielo A. Sládkoviča inšpirovali aj tvorbu Pavla Országha Hviezdoslava. Mladý básnik mu venoval svoju prvú zbierku Básnické prviesenky Jozefa Zbranského (1868) a aj dramatická skladba Vzhledanie (1868) odkazuje na Sládkoviča (Gbúr 2013:117).V tejto skladbe sa Andrej lúči so svojou milou Marínou, aby sa vydal do boja za vlast'. Autor explicitne pomenuje, že ide o konflikt medzi osobným a nadosobným, medzi devou a vlast'ou. Scéna lúčenia môže odkazovat' k Štúrovej predstave dramatickej poézie.

22 V liste A. Sládkoviča Pavlovi Dobšinskému z 2. apríla 1867 (cit. podla Kraus 1970: 255).

23 V liste A. Sládkoviča P. Dobšinskému z 2. apríla 1867 (cit. podla Kraus 1970: 255).

24 Bližšie k performatívnemu rozmeru kňazského, konkrétnejšie kazatel'ského povolania Poláčková 2019: 252-257. 
Stvárnenie Detvana vykazuje signifikantnú zhodu s ideálom slovanskej poézie, ako ju vo svojich prednáškach predostrel L'. Štúr. Sládkovič sa pravdepodobne stotožňoval so Štúrovými literárnoestetickými názormi aj na základe osobných preferencií; pri miere zhody má určitú úlohu spoločná inšpirácia Heglom a totožný kultúrny kontext. Istú rolu mohlo zohrat' aj prvotné neprijatie Maríny mladými predstavitel'mi národného hnutia sústredenými okolo L'. Štúra. Sládkovič začal koncipovat' Detvana ešte predtým, ako dosiahol čitatel'ský úspech a uznanie s Marínou. Marínu jeho „vrstovníci“ odmietli, čo Sládkovič prežíval tažko. Možno teda uvažovat' o tom, že po dočasnom neúspechu Maríny sa usiloval písat' „prijatel'nejšie“, t. j. vo vyššej miere aplikoval Štúrom navrhované charakteristiky ideálnej slovanskej poézie. Táto úvaha nechce byt' pristihovaním Sládkoviča pri oportunizme, skôr chce poukázat' na to, ako si básnik „hl'adal“ umelecké cesty k čitatel'om. V jednej sfére však Sládkovič ostal sám sebou a nad'alej sa rozchádzal so Štúrovou estetikou - jeho poetiku aj v Detvanovi charakterizuje subjektivizmus a téma romantickej lásky muža a ženy, avšak už nie v centrálnom postavení, ako to bolo v Maríne.

Rozsah styčných bodov vo sfére literárnoestetických východísk možno považovat' za dostatočné východisko na to, aby sa pri Detvanovi mohlo uvažovat' o aplikovatel'nosti Štúrom používaného termínu dramatická poézia. Znamenalo by to, že Sládkovič sa ambiciózne pokúsil o realizáciu slovanskej dramatickej poézie, ktorú Štúr hodnotil ako potenciálne najdokonalejšiu. Myslím si, že takýto predpoklad nie je v prípade Sládkoviča preexponovaný; popri svojej osobnej skromnosti to bol sebavedomý básnik, ktorý si trúfal na vysoké méty (Bilińska 2011:148-149).

Dokázat', do akej miery sa A. Sládkovič skutočne inšpiroval Štúrovými literárnoestetickými názormi, by bolo možné iba na základe priameho dôkazu z korešpondencie či iných dobových prameňov. Analytické čítanie skladby však poskytuje viacero indícií, že Detvan sa dá považovat' za realizáciu Štúrom načrtnutej estetickej koncepcie ideálnej slovanskej poézie.

Štúdia je výstupom kolektívneho grantového projektu VEGA 2/0107/19 Folklór, folkloristika a ideológia. Zodpovedný riešitel': Mgr. Zuzana Panczová, PhD. Doba riešenia: 2019-2022.

\section{Pramene}

AMBRUŠ, Jozef, ed., 1954. Listy L'udovita Štúra I. 1834 - 1843. Bratislava: Vydavatel'stvo Slovenskej akadémie vied.

AMBRUŠ, Jozef, ed., 1956. Listy L'udovita Štúra II. 1844 - 1855. Bratislava: Vydavatel'stvo Slovenskej akadémie vied.

AMBRUŠ, Jozef, ed., 1960. Listy L'udovita Štúra III. Dodatky. Bratislava: Vydavatel'stvo Slovenskej akadémie vied.

HEGEL, Georg Wilhelm Friedrich, 1970. Estetika. 2. zväzok. Bratislava:Vydavatel'stvo Epocha. KALINČIAK, Ján, 2009. Rozpomienky na Ondreja Sládkoviča. In KALINČIAK, Ján. Reštavrácia a iné. Bratislava: Kalligram - Ústav slovenskej literatúry SAV, s. 422-452.

KRAUS, Cyril, ed., 1970. Korešpondencia Andreja Sládkoviča. Martin: Matica slovenská.

SLÁDKOVIČ, Andrej, 1846. Ohlasy. Orol tatranský, roč. 2, č. 38, s. 297-298.

SLÁDKOVIČ, Andrej, 1961. Dielo. Ed. Cyril Kraus. Bratislava: Slovenské vydavatel'stvo krásnej literatúry.

ŠTÚR, Ludovít, 1987. O poézii slovanskej. Martin: Matica slovenská. 
VAJANSKÝ, Svetozár Hurban, 1956. State o slovenskej literatúre. Bratislava: Slovenské vydavatel'stvo krásnej literatúry.

VLČEK, Jaroslav, 1954. Kapitoly zo slovenskej literatúry. Bratislava: Slovenské vydavatel'stvo krásnej literatúry.

\section{Literatúra}

BILIŃSKA, Irena, 2011. Básnická pomsta. Andrej Sládkovič: Marína (1846). In Sondy do slovenskej literatúry 19. storočia. Bratislava: Kalligram - Ústav slovenskej literatúry SAV, s. $144-169$.

BILIŃSKA, Irena, 2014. Romantický básnik slobody. In SLÁDKOVIČ, Andrej. Dielo. Bratislava: Kalligram - Ústav slovenskej literatúry SAV, s. 731-749.

ČAVOJSKÝ, Ladislav, 1956. Príspevok k dejinám teórie drámy v šest'desiatych rokoch na Slovensku. Slovenské divadlo, roč. 4, č. 3-4, s. 282-293.

ČÚZY, Ladislav, 2004. Literárnoestetická koncepcia L'udovita Štúra v prednáškach o poézii slovanskej. Nitra: Univerzita Konštantína Filozofa.

ENCYKLOPÉDIA dramatických umeni Slovenska 1. A - L, 1989. Bratislava: Veda.

FOŘT, Bohumil, 2014. Fikčni světy české realistické prózy. Praha: Akropolis.

FREYTAG, Gustav, 1959. Technika drámy. Bratislava: Slovenské vydavatel'stvo krásnej literatúry. FRYE, Northrop, 2003. Anatomie kritiky. Brno: Host.

GBÚR, Ján, 2013. Vývinové premeny slovenskej dramatickej tvorby v období realizmu a moderny a Hviezdoslavova dráma. In Studia Slovakistica 13. Užgorod:Vidavnictvo Oleksandri Garkuši, s. 116-124.

HUČKOVÁ, Dana, 2017. Od reality k fantazijnej utópii: Hurbanove Korytnické poháriky. In KODAJOVÁ, Daniela - MACHO, Peter, ed. Jozef Miloslav Hurban - osobnost'v spoločnosti a reflexii. Bratislava: Veda - Historický ústav SAV, s. 206-220.

KLÁTIK, Zlatko, 1977. Slovenský a slovanský romantizmus. Typológia epických druhov. Bratislava: Veda.

KLEINSCHNITZOVÁ, Flora, 1958. Z našej romantiky. Bratislava: Slovenský spisovatel'. KRAUS, Cyril, 1959. Dráma v diele Andreja Sládkoviča. Slovenskédivadlo, roč. 7, č. 3, s. 181-207. KRAUS, Cyril, 1972. Andrej Sládkovič. Martin: Osveta.

KRAUS, Cyril, ed., 1980. Andrej Sládkovič. Život a dielo v dokumentoch. Martin: Osveta.

KRAUS, Cyril, 1983. Doslov. In SLÁDKOVIČ, Andrej. Detvan. Bratislava: Tatran, s. 125-130.

KROČANOVÁ, Dagmar, 2018. Nerozrezaná dráma. Bratislava: Univerzita Komenského.

MIHALKOVÁ, Gabriela, 2015. Žánre slovenského literárneho romantizmu. Prešov: Prešovská univerzita.

POLÁČKOVÁ, Eliška, 2019. Verbum caro factum est. Performativita bohemikální literatury 14. století pohledem divadelní vědy. Praha: Filosofia.

ŠMATLÁK, Stanislav, 1958. Poznámky k vývinu slovenskej epickej poézie. IV. Vel'ké skladby Andreja Sládkoviča. Slovenská literatúra, roč. 5, č. 3, s. 265-296.

VAJDA, Igor, 1988. Slovenská opera. Bratislava: Opus.

VELTRUSKÝ, Jiří, 1999. Drama jako básnické dílo. Brno: Nakladatelství Host.

VONGREJ, Pavol, 1987. Predslov. In ŠTÚR, L'udovít. O poézii slovanskej. Martin: Matica slovenská, s. 5-22.

WINCZER, Pavol, 1983. Sládkovičov Detvan a tradícia idyly. Slovenská literatúra, roč. 30, č. 4, s. 331-339.

Mgr. Marta Fülöpová, PhD.

Katedra slovenskej literatúry

a literárnej vedy

Filozofická fakulta Univerzity

Komenského

Gondova 2

81109 Bratislava

Slovenská republika

E-mail: marta.fulopova@uniba.sk 